\title{
Kompetencje użytkowników języka obcego. Wiedza socjokulturowa i kompetencja socjolingwistyczna studentów rusycystów
}

\author{
Competences of foreign language users. \\ Sociolinguistic competences and sociocultural knowledge \\ of Russian studies students
}

\begin{abstract}
The paper describes the assumptions of modern methods of teaching foreign languages, and this description includes the proposals of their creators regarding the knowledge that the student must acquire and the competences that he/she is to form. The results of the test checking sociocultural knowledge and sociolinguistic competences of Russian Studies students is also discussed. The low global result of the test (57\% of correct answers) showed a poor record of students in terms of the examined issues. Knowledge about Russia is very superficial among the study participants. They are also not good in dealing with contacts on the level of official relations (formal records of statements).
\end{abstract}

Keywords: sociolinguistic competences, sociocultural knowledge, Russian Studies student, teaching languages

Krystyna Janaszek, Uniwersytet Szczeciński, Szczecin - Polska, krystynajanaszek@interia.pl, ORCID ID: https://orcid.org/0000-0002-0488-3272

Teorie glottodydaktyczne XX wieku (audiolingwalna, kognitywna, komunikacyjna) opierały się na odmiennych podstawach językoznawczych i psychologicznych. Prezentowane w nich poglądy na język i zachowania (działania człowieka) rzutowały na koncepcje nauczania - uczenia się języków obcych. Zmieniały się zapatrywania na rolę uczącego się w procesie glottodydaktycznym, wiedzę, jaką musi sobie przyswoić, kompetencje, które ma ukształtować. $\mathrm{O}$ podstawowych założeniach metody audiolingwalnej przesądził behawioryzm - kierunek w psychologii XX wieku, który odrzucał rolę świadomości, a zachowanie człowieka sprowadził do działania w myśl formuły S (bodziec) - 
$\mathrm{R}$ (reakcja). Zgodnie z tym podejściem strukturaliści amerykańscy uznali język za zespół nawyków (Brzeziński 67).

Nauczanie - uczenie się języka obcego zdeterminowało pojęcie nawyku automatycznego (nieświadomego, mechanicznego), który w aspekcie lingwistycznym stanowi czynność językową wykonywaną przez człowieka poniżej progu świadomości (Pietrzyk 183-184). Lekcje polegały głównie na nauce wzorcowej wymowy i uczeniu się dialogów na pamięć, eliminowały więc traktowanie nauczania i uczenia się jako procesu intelektualnego. Rezygnowano z pełnego wykorzystania wiedzy, inteligencji i ciekawości uczących się (Woźniewicz 155). W efekcie ograniczono także możliwość rozwijania u uczniów umiejętności o charakterze komunikacyjnym, sprzyjających odnalezieniu się w różnych sytuacjach życia prywatnego czy społecznego. Wiedzę z zakresu geografii, kultury, historii, obyczajów i innych cech charakterystycznych społeczeństw używających danego języka jako narodowego przekazywano z reguły w formie krótkich wykładów (Ronowicz 163).

Dużą rolę w konstytuowaniu się metody kognitywnej odegrały założenia psychologii poznawczej. W jej ujęciu człowiek nie tylko reaguje na rzeczywistość, lecz także ją aktywnie tworzy (Włodarski, Matczak 115). Natomiast ustalenia Noama Chomsky’ego zmieniły pogląd na istotę języka. Według niego język nie jest systemem nawyków powstających drogą wielokrotnych powtórzeń, nie jest też zbiorem skończonych reakcji językowych (zdań). Jest systemem reguł, które trzeba opanować, aby móc tworzyć wypowiedzi na ich podstawie. Kompetencja zaś to znajomość reguł, którą odznacza się idealny użytkownik języka (Komorowska 2005: 28).

Położenie nacisku na intelektualno-poznawcze mechanizmy procesu akwizycji struktury gramatycznej, wyeksponowanie kompetencji językowej jako wiodącej w procesie przyswajania języka nie sprzyjało kształtowaniu umiejętności komunikowania się (skutecznego porozumiewania się). Pracę lekcyjną z tekstem o charakterze literackim czy realioznawczym podporządkowano analizom gramatycznym, co znacznie utrudniało realizację zadań związanych z przekazywaniem wartości kulturowych. Metoda kognitywna zwróciła wprawdzie uwagę na indywidualne właściwości uczącego się (np. strategie uczenia się), jednak nie zaproponowała ujęcia ich w ramy kompetencji.

Alternatywą dla koncepcji audiolingwalnej i kognitywnej stało się podejście komunikacyjne, najpowszechniejsze obecnie w nauczaniu języków obcych. Opisując je, można odwołać się do wielu różnych nurtów w psychologii i językoznawstwie. Czynnościowe podejście do przedmiotu psychologii zaproponowali badacze rosyjscy. Psychologia czynności analizuje współdziałanie człowieka z otoczeniem, rozpatrywane jako proces rozwiązywania zadań (Tałyzina 28-31). 
Reprezentatywne dla glottodydaktyki rosyjskiej podejście komunikacyjno-czynnościowe uwzględnia aspekt społeczny akwizycji języka. Podkreśla się w nim, że komunikacja dokonuje się w układach społecznych, a czynności mowne pojawiają się wtedy, gdy zachodzi potrzeba autentycznego porozumiewania się w celu współdziałania ludzi. W tym kontekście ważne staje się pojęcie kompetencji komunikacyjnej, na którą składa się kompetencja językowa (odzwierciedlająca poprawność gramatyczną) i społeczno-kulturowa (odzwierciedlająca przyjęty przez daną wspólnotę zwyczaj użycia wymaganych w określonym kontekście wyrażeń językowych). Podejście to, w odróżnieniu od poprzednich metod, w sposób zdecydowany zaakcentowało socjalno-kulturowy aspekt przyswajania języka obcego (Gawarkiewicz 205).

Spojrzenie na naukę języków obcych przełomu wieków XX i XXI wypełnia się coraz to nowymi treściami. Mocniej akcentuje się fakt, że język stanowi nieodłączną część cywilizacji i kultury społeczeństwa będącego jego użytkownikiem, występuje w roli składnika kultury narodowej. Jako zjawisko społeczne jest narzędziem socjalizacji, kształtuje osobowość jego użytkowników. Na znaczeniu zyskuje koncepcja kształcenia komunikacyjnego jako propozycja rozwoju indywidualności w dialogu kultur. Rolę międzykulturowego dialogu sygnalizują liczne dokumenty publikowane na przełomie wieków. Zwraca się w nich uwagę na kwestie szacunku i tolerancji dla przekonań, wartości i zachowań ludzi innych narodów. Formułowane wytyczne mają służyć ich zbliżeniu poprzez eliminację barier językowych i kulturowych (Komorowska 1996: 10).

Ważnym dokumentem staje się Europejski system opisu ksztatcenia językowego: uczenie się, nauczanie, ocenianie. Zaznacza się w nim, że język jest nie tylko istotnym elementem kultury, lecz także środkiem dostępu do jej wytworów. Posługiwanie się nim obejmuje działania podejmowane przez uczestników życia społecznego, którzy - jako osoby indywidualne - zdobyli i stale rozwijają swoje kompetencje, zarówno ogólne (niezwiązane z językiem), jak i językowe kompetencje komunikacyjne (Coste et al. 20). Do tych pierwszych zalicza się m.in. wiedzę deklaratywną i uwarunkowania osobowościowe. Na kompetencję komunikacyjną składają się: kompetencje lingwistyczne (np. gramatyczna, ortograficzna), kompetencja socjolingwistyczna oraz pragmatyczna. Pozwalają one użytkownikowi życia społecznego działać za pomocą języka (Coste et al. 94-114).

Wiedza socjokulturowa i kompetencja socjolingwistyczna znalazły się w polu moich zainteresowań badawczych. Wiadomości o społeczeństwie i jego kulturze stanowią pewien aspekt ogólnej wiedzy o świecie. Mogą one dotyczyć:

- codziennego życia (np. potrawy, napoje, święta państwowe);

- systemów wartości, poglądów, postaw w zakresie takich czynników, jak: tradycja a przemiany społeczne, historia, polityka, religia, sztuka: muzyka, literatura, teatr, piosenka (Coste et al. 95). 
Kompetencja socjolingwistyczna obejmuje m.in.:

1. Wyznaczniki relacji społecznych, zróżnicowane w różnych kulturach i językach, zależne od pewnych czynników, którymi są: stopień pokrewieństwa, zażyłość relacji, rejestr wypowiedzi. Wśród nich można wymienić:

- użycie i wybór form powitania (przy wejściu i wyjściu);

- użycie i wybór form adresatywnych (np. sztywne, formalne, nieformalne, poufałe).

2. Konwencje grzecznościowe, odmienne w różnych kulturach, stanowiące często źródło interkulturowych nieporozumień. Szczególną uwagę zwraca się na tzw. grzeczność pozytywną (np. wykazywanie zainteresowania samopoczuciem drugiej osoby).

3. Nośniki mądrości ludowej - istotny składnik kultury popularnej. Należą do nich przysłowia, czyli „lapidarne, treściwe sformułowania (bezpośrednie lub przenośne) jakichś prawd ogólnych, wspólnych dla tych grup społecznych, z których doświadczeń się wywodzą" (Nyczaj 5).

4. Rejestr wypowiedzi, czyli systemowe zróżnicowanie wariantów języka stosowanych $\mathrm{w}$ określonych kontekstach. W tym miejscu warto wskazać na zróżnicowanie stopnia formalności wypowiedzi, które mogą być: sztywne, formalne, neutralne, nieformalne, poufałe (Coste et al. 106-107).

W badaniach testowych, które przeprowadziłam w roku akademickim 2018/2019, wzięli udział studenci z Uniwersytetu Szczecińskiego z drugiego i trzeciego roku studiów stacjonarnych (filologia rosyjska). Badania przeprowadziłam na zasadzie próby dostępnej, to znaczy takiej, do której jako badaczka miałam ułatwiony dostęp. Na zajęciach językowych rozdałam studentom 60 egzemplarzy testów. Po ich zebraniu okazało się, że tylko 32 można zakwalifikować do analizy empirycznej. Grupa 32-osobowa to mała próba badawcza i nie należy na jej podstawie dokonywać jakichkolwiek uogólnień. Można jednak uzyskać wiele cennych informacji, przydatnych w toku kształcenia językowego. Test badał kompetencję socjolingwistyczną i wiedzę socjokulturową studentów. Uzyskano także dane na temat kompetencji lingwistycznych. W tabeli 1 zaprezentowałam globalne wyniki badań.

Tabela 1. Wyniki globalne testu badającego kompetencję socjolingwistyczną i wiedzę socjokulturową studentów rusycystów

\begin{tabular}{|c|c|c|c|c|}
\hline $\begin{array}{c}\text { Numer zadania/ } \\
\text { badany obszar wiedzy } \\
\text { i umiejętności }\end{array}$ & $\begin{array}{c}\text { Liczba studentów } \\
\text { uczestniczących } \\
\text { w badaniu }\end{array}$ & $\begin{array}{c}\text { Liczba punktów } \\
\text { możliwych do } \\
\text { uzyskania przez } \\
\text { jednego studenta }\end{array}$ & $\begin{array}{c}\text { Liczba punktów } \\
\text { możliwych do } \\
\text { uzyskania przez } \\
\text { wszystkich } \\
\text { studentów }\end{array}$ & $\begin{array}{c}\text { Liczba punktów } \\
\text { uzyskanych } \\
\text { w teście przez } \\
\text { wszystkich } \\
\text { studentów }\end{array}$ \\
\hline $\begin{array}{c}\text { 1. Kompetencja } \\
\text { socjolingwistyczna }\end{array}$ & 32 & 5 & 160 & 119 \\
\hline
\end{tabular}




\begin{tabular}{|l|c|c|c|c|}
\hline $\begin{array}{c}\text { 2. Kompetencja } \\
\text { socjolingwistyczna }\end{array}$ & 32 & 4 & 128 & 52 \\
\hline $\begin{array}{c}\text { 3. Kompetencja } \\
\text { socjolingwistyczna }\end{array}$ & 32 & 6 & 192 & 110 \\
\hline $\begin{array}{c}\text { 4. Wiedza } \\
\text { socjokulturowa }\end{array}$ & 32 & 10 & 320 & 175 \\
\hline Ogółem & 32 & 25 & 800 & 456 \\
\hline
\end{tabular}

Na potrzeby badań przyjęłam także podział na rodzaje wyników, który uwzględnił następujące ich kategorie:

1. Wyniki wysokie: $100-90 \%$

2. Wyniki satysfakcjonujące: $89-80 \%$

3. Wyniki zadowalające: $79-70 \%$

4. Wyniki w miarę zadowalające: $69-60 \%$

5. Wyniki niskie: $59-50 \%$

6. Wyniki niezadowalające: $49-40 \%$

Spośród czterech proponowanych $\mathrm{w}$ teście zadań studenci najlepiej poradzili sobie z pierwszym. Siedem osób (23\%) otrzymało za wykonanie tego zadania maksymalną liczbę punktów (5), pozostałe uzyskały od 2 do 4 punktów. Procent odpowiedzi poprawnych wyniósł 74,4, co w kategorii rodzaju wyników daje wartość zadowalającą.

Poniżej prezentuję zadania wraz z przykładowymi wypowiedziami uczestników badania w ramach poszczególnych podpunktów:

Zadanie 1. Spotykasz kolegę, którego dawno nie widziałeś(-aś):

a) przywitaj się z nim, używając odpowiedniej formy adresatywnej:

- Привет, моя дорогая подруга!

- Привет, Аня, сто лет тебя не видела!

- Привет, дружище! Сколько лет, сколько зим!

b) wyraź zadowolenie ze spotkania:

- Как же я рад тебя видеть! Мы так давно с тобой не виделись!

- Я очень рада тебя видеть! Мы не виделись, кажется, 100 лет!

- Я очень рада тому, что мы, наконец-то, встретились!

c) zapytaj o samopoczucie i o to, co słychać:

- Расскажи, как у тебя дела, что нового?

- Как дела? Что нового? Как твое здоровье сейчас? Помню, при нашей последней встрече ты жаловалась на частые головные боли.

- Как у тебя дела? Как твоя семья? Как дети? Я видела их совсем маленькими. Чем они занимаются? 
d) zaproś go na swoje urodziny:

- Знаешь, у меня через неделю День рождения и я буду очень рада тебя видеть. Приходи вместе с мужем в субботу, в 19:00 часов, в кафе „Найка”.

- Ты знаешь, что в пятницу у меня День рождения. Я очень хочу тебя видеть на моем празднике. Приглашаю тебя в ресторан, в пятницу, в 19:00.

- Давай встретимся в неформальной обстановке. Приглашаю тебя завтра на мой День рождения. Моя семья будет очень рада встрече! Приходи к нам по старому адресу, к 18 часам.

e) pożegnaj się, życząc wszystkiego najlepszego:

- До встречи. Всего хорошего!

- До встречи. Удачи тебе!

- Ну, пока! До встречи. Ждем тебя!

- До встречи. Не забудь, завтра у меня дома, в пять. Пока!

Choć w pracach pojawiły się błędy gramatyczne i ortograficzne, nie zakłócały one komunikatywności przekazu. Punkty odejmowałam wyłącznie za brak wymaganej informacji. $\mathrm{W}$ tabeli 2 i 3 prezentuję przykłady błędów w ramach kompetencji lingwistycznej.

Kompetencja gramatyczna (znajomość i umiejętność stosowania gramatycznych środków językowych)

Tabela 2. Błędy gramatyczne

\begin{tabular}{|l|l|}
\hline Forma poprawna & Forma błędna \\
\hline Выпить стакан водки & Выпить стакана водки \\
\hline Позвони мне & Позвони меня \\
\hline К моей бабушке & К мою бабушке \\
\hline Я рад тебя видеть & Я рад тебе видеть \\
\hline На этой неделе & В эту неделю \\
\hline Я рад, что тебя вижу & Я рад, что тебе вижу \\
\hline Приглашаю тебя & Приглашаю тебе \\
\hline У меня дома & У меня в доме \\
\hline Три месяца & Три месяцы \\
\hline Желаю тебе всего хорошего & Желаю тебя всё хорошо \\
\hline
\end{tabular}

Kompetencja ortograficzna (poprawność ortograficzna)

Tabela 3. Błędy ortograficzne

\begin{tabular}{|l|l|}
\hline Forma poprawna & Forma blędna \\
\hline Я желаю счастья & Я желаю счастия \\
\hline
\end{tabular}




\begin{tabular}{|l|l|}
\hline Я не пью & Я не пию \\
\hline Я надеюсь & Я надеюс \\
\hline Теперь & Тепер \\
\hline Понедельник & Понеделник \\
\hline Сколько & Сколко \\
\hline Здоровье & Здорове \\
\hline Отлично & Отличьно \\
\hline Маленькие & Маленкие \\
\hline День рождения & День раждения \\
\hline Щецинский университет & Щецинский Университет \\
\hline
\end{tabular}

Wśród błędów gramatycznych najczęściej pojawiało się mylenie zaimków wewnątrz paradygmatu (np. тебя - тебе). Analiza błędów ortograficznych dowiodła, że wynikają one z nieznajomości i/lub braku umiejętności stosowania zasad pisowni znaku miękkiego w funkcji zmiękczającej i rozdzielającej.

W omawianym zadaniu w większości prac zastosowano odpowiednie konwencje grzecznościowe, respektując zasady tzw. grzeczności pozytywnej (np. „Как дела? Что нового? Как твое здоровье сейчас?”). Posługiwano się prawidłowymi, stosownymi do okoliczności formami powitania i pożegnania (np. „Привет, моя дорогая подруга”, „До встречи. Удачи тебе!”), korzystano z form adresatywnych o charakterze nieformalnym (nр. „Привет, Аня!”), сzasami nawet bardziej poufałym (np. „Привет, дружище!”). Zastosowany w pracach rejestr nieformalny odpowiadał sygnalizowanej w teście sytuacji z życia codziennego.

Zadanie 2. Wystosuj pisemne zaproszenie do określonej, ważnej osoby (może to być profesor, pracodawca) na doniosłą dla Ciebie uroczystość (np. rozdanie dyplomów, ślub).

W tym punkcie testu należało nadać przekazywanej informacji charakter bardziej formalny od poprzedniego. Wyniki okazały się niezadowalające, otrzymałam tylko 40,6\% odpowiedzi poprawnych. Zaledwie pięć spośród badanych osób (15,6\%) uzyskało maksymalną liczbę punktów (4). Oto przykład zaproszenia ocenionego na wysoką notę:

Уважаемый Иван Петрович!

Приглашаем Вас вместе с супругой на церемонию нашего бракосочетания, которая состоится во Дворце бракосочетаний 21.05.2019 г. в 13:00 часов.

С уважением Иван и Мария 
Aż jedenaście osób $(34,4 \%)$ w ogóle nie przystąpiło do wykonania tego zadania. Pozostała część badanych nie poradziła sobie z poszczególnymi częściami pisma. Brakowało: odpowiednich nagłówków, informacji, kto jest zapraszany, z jakiej okazji zaproszenie zostało wysłane, kiedy i gdzie odbędzie się uroczystość i kto zaprasza. W wielu przypadkach formuła grzecznościowa rozpoczynająca tekst odbiegała od oficjalnego charakteru zaproszenia. Używano zwrotów: „Здравствуйте” albo „Добрый день”. Trudność sprawiało także użycie zwrotu kończącego pismo; pojawiały się propozycje niepasujące do nakreślonej w teście sytuacji (np. „Жду вашего ответа”, „До скорой встречи”, „Поздравляю Вас”).

Zadanie 3. Napisz przysłowia odnoszące się do wierzeń, postaw i poglądów, wartości oraz innych zdarzeń i spraw.

Przytoczono łącznie 110 wyrażeń związanych z mądrością ludową. Na jednego studenta przypadły przeciętnie 3-4 przysłowia. Jednak prawie połowa uczestników badania (44\%) nie podjęła się wykonania zadania i tym samym otrzymała 0 punktów. Pozostali zdobyli ich od 1 do 6 . Procent odpowiedzi poprawnych wyniósł 57,3. Oto przykłady przysłów, które cytowano najczęściej:

Без труда не вытащишь и рыбку из пруда (5 razy).

В здоровом теле - здоровый дух (5 razy).

Яблоко от яблони недалеко падает (5 razy).

Береженого Бог бережет (4 razy).

Тише едешь - дальше будешь (3 razy).

Век живи - век учись (3 razy).

Pojedynczo występowały następujące:

Осень идет - дожди за собой ведет.

Много снега - много хлеба.

Кошка к печке - холод во двор.

Жизнь прожить - не поле перейти.

Сытый голодному не товарищ.

Что посеешь, то и пожнешь.

Не все то золото, что блестит.

Zadanie 4. Napisz do kolegi list i pochwal się wiedzą o Rosji, którą zdobyłeś w trakcie studiów. Przekazywane informacje mogą dotyczyć różnych obszarów (np. tradycji, historii, polityki, religii, sztuki).

W tym przypadku maksymalną liczbę punktów (10) otrzymało $22 \%$ badanych, pozostali uzyskali ich od 1 do 8 . Odsetek odpowiedzi poprawnych $(54,7 \%)$ był niski. Najczęściej opisywano: miasta rosyjskie, tradycje, politykę i historię, ludzi (naród). Oto fragmenty listów: 
Miasta

Москва очень красивый город, в нем есть что посмотреть! Побывала на Красной площади, Арбате, ВДНХ, в Третьяковской галерее. Особенно впечатлило меня Московское метро.

Санкт-Петербург был построен русским царем Петром Первым в 1703 году. В свое время был столицей Российской империи. С того времени в Питере (а именно так его называют местные жители) находятся прекрасные здания, например Зимний дворец. Особенностью являются „белые ночи”.

\section{Tradycje}

Новый год русские встречают всей семьей. В полночь они слушают обращение президента и пьют шампанское.

Также они празднуют 8-ое Марта. Мужчины дарят женщинам и девушкам на улицах города цветы.

Масленица - это очень интересный праздник, много блинов с различной начинкой, такой как: варенье, красная икра, рыба. Очень много различных национальных напитков: квас, медовуха. Люди водят хороводы и поют песни.

\section{Historia/polityka}

Мне очень жаль, что во все времена власть этой могучей державы жестоко относилась к своему народу. Меня очень впечатлила история Колымы и Гулага. Больно смотреть на то, что делали с людьми в концлагерях. При этом в голове не укладывается, почему народ так прославляет Сталина (его действия поражают до глубины души). Сейчас в России другие времена и другая власть, но как и раньше люди все равно прославляют своего Вождя - президента России Владимира Путина.

В стране тотальная коррупция и отсутствие демократии. Власть на протяжении почти 20 лет в руках у одного человека.

\section{Ludzie/naród}

Народ в России очень веселый, с хорошим чувством юмора, но о власти шутить не стоит.

Мне очень нравится русский народ. Россияне много читают, часто ходят в театр и в кино.

Русские люди добрые и сердечные, но истории не знают хорошо, потому, что в учебниках и по телевидению много пропаганды. 
Wypowiedzi studentów na temat władzy państwowej kontrastują z tymi dotyczącymi narodu rosyjskiego. Krytyczny stosunek do państwa i jego historii przeciwstawiany jest pozytywnej ocenie zwykłych ludzi. Stanowisko takie jest często spotykane wśród Polaków.

Znajomość literatury rosyjskiej jest pośród studentów skromna. Potrafią oni wymienić pisarzy i poetów, jednak w ogóle nie ustosunkowują się do ich twórczości. Wśród nazwisk powtarzających się najczęściej występują: Aleksander Puszkin, Fiodor Dostojewski, Lew Tołstoj, Anna Achmatowa. W ramach wiedzy o teatrze podawane jest nazwisko Iwana Wyrypajewa. Pośród ulubionych filmów znalazł się obraz Moskwa nie wierzy łzom. Fascynacje muzyczne studentów koncentrują się na młodzieżowych zespołach rockowych.

Niski globalny wynik testu wskazuje na braki studentów w zakresie wiedzy socjokulturowej i kompetencji socjolingwistycznej. W przeciwieństwie do sytuacji o charakterze oficjalnym, kontakty w sferze relacji życia codziennego nie stwarzają badanym większych problemów. Relacje o charakterze bardziej formalnym mogą być jednak zakłócone i prowadzić do nieporozumień. Wiedza o Rosji większości uczestników testu jest powierzchowna, trudno więc będzie się nią pochwalić i wykorzystać w kontaktach z rodzimymi użytkownikami języka.

Fakt niesatysfakcjonujących rezultatów testu należy wiązać z czynnikami natury obiektywnej i subiektywnej. W pierwszym przypadku trzeba zwrócić uwagę na ograniczoną liczbę godzin przeznaczonych na studiowanie języka obcego. Plan studiów przewiduje ich niewiele na zajęcia poświęcone kulturze czy realiom badanego obszaru językowego. Niekorzystna sytuacja w tym zakresie nie sprzyja zgłębieniu wiedzy i opanowaniu odpowiednich umiejętności na właściwym poziomie. Kolejny problem, który warto przy okazji tych badań zasygnalizować, to uwarunkowania subiektywne (kompetencje ogólne). Tylko ok. 20\% uczestników badania uzyskało w przeprowadzonym teście wyniki wysokie. Jest to grupa studentów wyróżniających się, którzy w toku studiów osiągają średnią ocen 4,5-5,0. Pozostała część badanej próby to studenci dostateczni (średnia ocen 3,0-3,5). Obie grupy różnią się od siebie właściwościami osobowościowymi mającymi bezpośrednie przełożenie na wyniki studiowania. Dowodzą tego moje wcześniejsze badania obejmujące dwie sfery osobowości: intelektualną i afektywną (Janaszek 160-163). Przykład grupy studentów bardzo dobrych dowodzi, że na płaszczyźnie intelektualnej (kognitywnej) ważne są różne rodzaje inteligencji i uzdolnień językowych, takich jak choćby inteligencja językowa i zdolność do analizy językowej. Przyczyniają się one do poprawności wypowiedzi obcojęzycznej. Ważne są także sposoby podejścia do zjawisk językowych. Liczy się tu szczególna umiejętność porządkowania faktów językowych w logiczne reprezentacje oraz zdolność wnioskowania i akceptowania niejednoznaczności pojawiających się w systemie języka. Powodzenie w nauce warunkują wysoko wskaźnikowane procesy pamięci i charakterystyczne dla nich cechy (szybkość, pojemność, trwałość, gotowość, wierność). Zależy od nich nie 
tylko łatwość zapamiętywania, lecz ich obecność umożliwia także właściwe gromadzenie i przechowywanie danych językowych. W sferze afektywnej (emocjonalno-uczuciowej) znaczącą rolę odgrywają właściwości temperamentalne i związane z nimi cechy takie jak: solidność, zrównoważenie, aktywność, obowiązkowość, pracowitość, pilność, dokładność, pojętność. Bardzo dobre wyniki w nauce wspomaga instrumentalno-integrująca motywacja o charakterze wewnętrznym aktywizująca motywy poznawcze, a także silna potrzeba osiągnięć i chęć samodoskonalenia. Umiejętność zarządzania trudną sytuacją problemową w dużym stopniu minimalizuje pojawianie się w toku nauki emocji negatywnych, sprzyja zaś emocjom pozytywnym, które podtrzymują działalność intelektualną na wysokim poziomie. Brak wyszczególnionych wyżej kompetencji osobowościowych ogranicza możliwość osiągnięcia wysokich rezultatów kształcenia językowego. Studentów dostatecznych charakteryzują skromniejsze walory intelektualne, wyrażające się mniejszymi zdolnościami językowymi, niżej wskaźnikowaną inteligencją i pamięcią. Dużą rolę wśród czynników hamujących sukces odgrywa brak sumienności i chęci do samodzielnego doskonalenia własnych umiejętności, a także mniejsze możliwości radzenia sobie z negatywnymi emocjami i stresem.

\section{Bibliografia}

Brzeziński, Jerzy. Nauczanie języków obcych dzieci. Warszawa, Wydawnictwa Szkolne i Pedagogiczne, 1987.

Coste, Daniel et al. Europejski system opisu ksztatcenia językowego: uczenie się, nauczanie, ocenianie. Warszawa, Centralny Ośrodek Doskonalenia Nauczycieli, 2003.

Gawarkiewicz, Roman. „Uwagi na temat implikacji glottodydaktycznych pragmalingwistycznej teorii aktów mowy". Slavica Stetinensia, 7, 1998, s. 205-219.

Janaszek, Krystyna. Intelektualna i afektywna sfera osobowości studenta neofilologa. Szczecin, Wydawnictwo Naukowe Uniwersytetu Szczecińskiego, 2018.

Komorowska, Hanna. Metodyka nauczania języków obcych. Warszawa, Wydawnictwo Fraszka Edukacyjna, 2005.

Komorowska, Hanna. „Nowe tendencje w pracach programowych Rady Europy”. Języki Obce w Szkole, 2, 1996, s. 109-115.

Nyczaj, Stanisław. Mała księga przysłów polskich. Radom, Oficyna Wydawnicza STON I, 1994.

Pietrzyk, Izabela. „Problematyka nawyku językowego w świetle koncepcji kognitywnej”. Slavica Stetinensia, 7, 1998, s. 191-204.

Ronowicz, Edmund. Kierunki w metodyce nauczania języków obcych. Warszawa, Wydawnictwa Szkolne i Pedagogiczne, 1982.

Tałyzina, Nina. Kierowanie procesem przyswajania wiedzy. Przeł. Maria Ewa Pytlowska. Warszawa, Wydawnictwa Szkolne i Pedagogiczne, 1980.

Włodarski, Ziemowit, Anna Matczak. Wprowadzenie do psychologii. Podręcznik dla nauczycieli. Warszawa, Wydawnictwa Szkolne i Pedagogiczne, 1998.

Woźniewicz, Władysław. Kierowanie procesem glottodydaktycznym. Warszawa, Państwowe Wydawnictwo Naukowe, 1987. 